University of Nebraska - Lincoln

DigitalCommons@University of Nebraska - Lincoln

\title{
Geochemical Evidence for Hydroclimatic Variability over the Last 2460 Years from Crevice Lake in Yellowstone National Park, USA
}

Lora R. Stevens

California State University-Long Beach, lora.stevens@csulb.edu

Walter E. Dean

U.S. Geological Survey, Denver, CO, dean@usgs.gov

Follow this and additional works at: https://digitalcommons.unl.edu/usgsstaffpub

Part of the Earth Sciences Commons

Stevens, Lora R. and Dean, Walter E., "Geochemical Evidence for Hydroclimatic Variability over the Last 2460 Years from Crevice Lake in Yellowstone National Park, USA" (2008). USGS Staff -- Published Research. 321.

https://digitalcommons.unl.edu/usgsstaffpub/321

This Article is brought to you for free and open access by the US Geological Survey at DigitalCommons@University of Nebraska - Lincoln. It has been accepted for inclusion in USGS Staff -- Published Research by an authorized administrator of DigitalCommons@University of Nebraska - Lincoln. 


\title{
Geochemical evidence for hydroclimatic variability over the last 2460 years from Crevice Lake in Yellowstone National Park, USA
}

\author{
Lora R. Stevens ${ }^{\mathrm{a}, *}$, Walter E. Dean ${ }^{\mathrm{b}}$ \\ ${ }^{a}$ Department of Geological Sciences, California State University-Long Beach, Long Beach, CA 90840-3902, USA \\ ${ }^{\mathrm{b}}$ United States Geological Survey, Earth Surface Processes, MS 980, Denver, CO 80225, USA
}

Available online 19 November 2007

\begin{abstract}
A 2460-year-long hydroclimatic record for Crevice Lake, Yellowstone National Park, Montana was constructed from the $\delta^{18} \mathrm{O}$ values of endogenic carbonates. The $\delta^{18} \mathrm{O}$ record is compared to the Palmer Hydrologic Drought Index (PHDI) and Pacific Decadal Oscillation (PDO) indices, as well as inferred discharge of the Yellowstone River. During the last century, high $\delta^{18} \mathrm{O}$ values coincide with drought conditions and the warm phase of the PDO index. Low $\delta^{18} \mathrm{O}$ values coincide with wet years and a negative PDO index. Comparison of tree-ring inferred discharge of the Yellowstone River with the $\delta^{18} \mathrm{O}$ record over the last 300 years indicates that periods of high discharge (i.e., wet winters with significant snow pack) correspond with low $\delta^{18} \mathrm{O}$ values. Extrapolating this relationship we infer wet winters and high river discharge for the periods of 1090-1030, 970-870, 670-620, and 500-430 cal years BP. The wet intervals at 670 and $500 \mathrm{cal}$ BP are synchronous with similar events in Banff, Canada and Walker Lake, Nevada. The wet intervals at 970 and 670 cal BP overlap with wet intervals at Walker Lake and major drought events identified in the western Great Basin. These results suggest that the northern border of Yellowstone National Park straddles the boundary between Northern Rocky Mountains and Great Basin climate regimes. (C) 2007 Elsevier Ltd and INQUA. All rights reserved.
\end{abstract}

\section{Introduction}

Natural variability within the hydroclimates of western North American mountain ranges has become a key issue given that climatic changes over the last several decades have resulted in earlier timing of snowmelt (Cayan et al., 2001; Stewart et al., 2005) and in observed decreases in snow pack and snow water equivalent at mid to high elevations (Mote et al., 2005; Regonda et al., 2005). Much of the change in snowmelt timing is attributed to broadscale increases in winter and spring temperatures rather than decadal variations in synoptic climate features (Stewart et al., 2005). Models suggest that the trend to earlier snowmelt will increase throughout the next century (Stewart et al., 2004). The apparent sensitivity of snow pack to changes in mean winter temperatures could have significant repercussions for many United States river systems and several major aquifer systems with increased global warming. However, given the climatic heterogeneity

\footnotetext{
${ }^{*}$ Corresponding author. Tel.: + 15629854817 ; fax: +15629858638 .

E-mail address: 1steven2@csulb.edu (L.R. Stevens).
}

of mountainous regions (Mock, 1996), region-specific studies of temperature and precipitation trends are necessary to fully assess the possible range of hydrologic response to climate change in the western United States.

This paper focuses on hydrologic changes over the last 2460 years in the northern range of Yellowstone National Park (YNP), Wyoming and Montana (Fig. 1). The Yellowstone Plateau is the headwater region for the Yellowstone River, a major tributary of the Missouri River and the longest unrestricted river in the continental US. Peak discharge along the upper reaches of the Yellowstone occurs in May and June (USGS-National Water Information System, n.d.) and is highly dependent on the amount of snowmelt derived from the mountains that surround Yellowstone Lake, the source of the Yellowstone River. Thus, long-term variability in discharge is likely to reflect changing amounts of snow pack related to winter drought.

Tree-rings have been used to successfully document pre-instrumental discharge of rivers and streams (e.g., Smith and Stockton, 1981; Cleaveland and Stahle, 1989; Woodhouse, 2001; Graumlich et al., 2003). Unfortunately, 


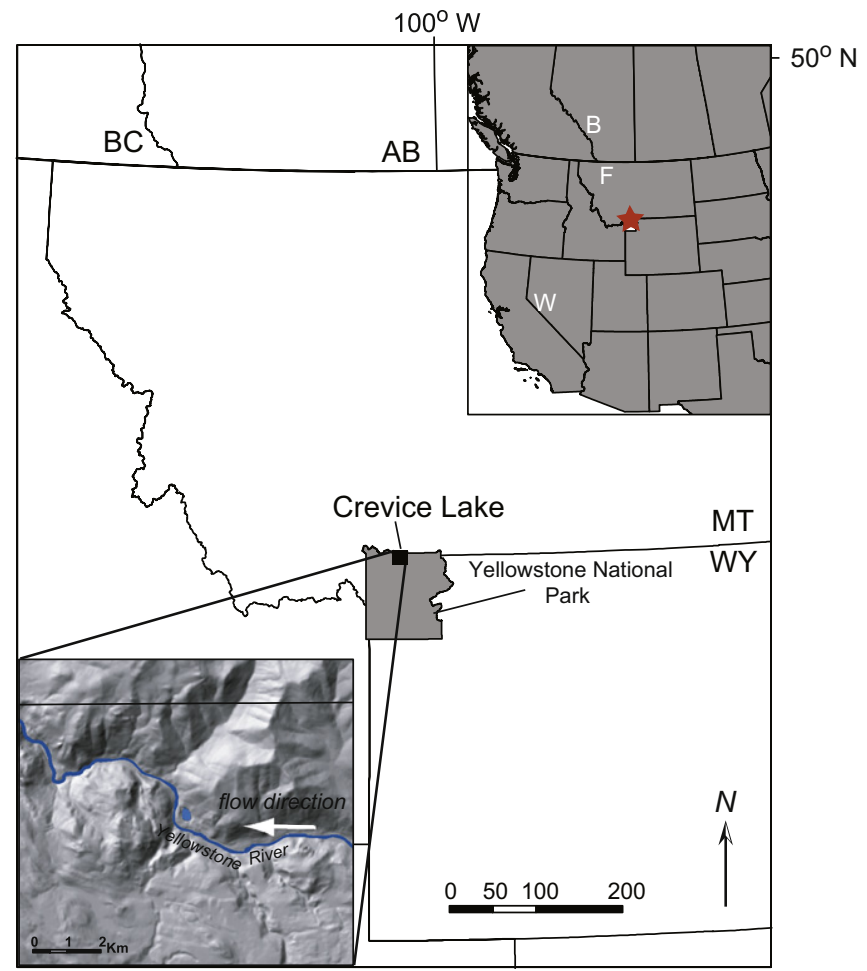

Fig. 1. Map of Montana, Wyoming, and Idaho showing the location of Yellowstone National Park (in gray) with the location of Crevice Lake (black square). Inset (upper right corner) shows the location of Yellowstone National Park relative to the western United States. B, F, and W indicate locations of Banff, Canada; Foy Lake, Montana; and W, Walker Lake, Nevada, respectively. Inset (lower left corner) is a digital elevation model of the Black Canyon of the Yellowstone showing the position of Crevice Lake relative to the Yellowstone River. White arrow indicates direction of stream flow. North is the same direction in all figures (Figure courtesy of Whitlock et al., this volume).

very few tree-ring based reconstructions extend back further than a few hundred years. Lakes, which can archive uninterrupted sequences of sediment over thousands of years, may be able to extend discharge estimates beyond tree-ring records, if the lake is sensitive to hydrologic variability of the river system. River/lake relationships have been described for glaciated prairie sites (e.g., Almendinger, 1990). However, due to the narrow valleys typical of mountainous regions, few lakes are positioned within a watershed to permit a direct and straightforward hydrologic link with a specific river. We present here a sub-decadal, geochemical record from Crevice Lake, Montana that relates $\delta^{18} \mathrm{O}$ variations to discharge of the Yellowstone River and, thus, qualitatively extends stream flow and winter season climate variability back to 2460 cal BP.

This paper is part of a series that examines climatic change at Crevice Lake from various angles through multiple proxies. The hydroclimatic reconstruction outlined in this paper and the limnological response of the lake to climate change inferred from the diatom assemblage (Bracht et al., this volume) are added to trace element, magnetic susceptibility, pollen, and charcoal data to provide a broader climatic reconstruction discussed in Whitlock et al. (this volume).

\section{Site description}

Crevice Lake, Montana $\left(45^{\circ} 00^{\prime} \mathrm{N}, 110^{\circ} 34.7^{\prime} \mathrm{W}\right.$, ca. $1713 \mathrm{~m}$ a.s.1.) occupies a bowl-shaped basin approximately $260 \mathrm{~m}$ east of the Yellowstone River (Fig. 1, bottom left inset). The geographic position of the lake is unusual in that that it is located in a narrow gorge (Black Canyon of the Yellowstone) dissecting Precambrian metamorphic rocks. The lake occupies a basin located at a bend in the river and is separated from it by a ridge, $25 \mathrm{~m}$ high, of unconsolidated, reworked till. A steep talus slope bounds the lake on the east. The basin has a small area $\left(0.08 \mathrm{~km}^{2}\right)$, maximum depth of $31 \mathrm{~m}$, and no active inlet or outlet. Water column profiles of salinity, temperature, and dissolved oxygen were measured in July 1996 and February 2001 and show a distinct chemocline between 15 and $16 \mathrm{~m}$. The hypolimnion was anoxic. However, it is unknown if the lake is permanently anoxic (meromictic).

\section{Methods}

The deep basin of the lake was cored from the ice in February 2001 with both a modified square-rod Livingston piston corer and a UWITECH ${ }^{\circledR}$ percussion piston corer. A freeze-core collected the sediment/water interface. Two overlapping Livingstone cores and four overlapping UWITECH $^{\circledR}$ cores were retrieved, split longitudinally, and photographed in $10 \mathrm{~cm}$ intervals. The photographs provide an archive of sample locations and thickness, macrofossil locations, and general sedimentary changes. The Livingstone cores were archived, and all sampling was done on the 8 -cm diameter UWITECH ${ }^{\circledR}$ cores. Contiguous samples were collected at $2-4 \mathrm{~mm}$ intervals over the upper $112 \mathrm{~cm}$ (one drive section). The entire section was finely laminated, and we assume that the laminations represent annual increments of sedimentation (i.e., varves). Laminations within each sample were counted three times to provide a varve chronology. Cuts were made parallel to bedding planes. The average sample was $3 \mathrm{~mm}$ thick, representing an average of 7 years. One aliquot of each sample was packed while wet into a $3.2 \mathrm{~cm}^{3}$ plastic cube for magnetic and geochemical measurements at the USGS in Denver, CO. The remaining sample was then homogenized prior to division into aliquots for isotope and diatom analyses (see Whitlock et al., this volume).

Concentrations of total carbon (TC) and total inorganic carbon (TIC) were determined by coulometric titration of $\mathrm{CO}_{2}$ following extraction from the sediment by combustion at $950^{\circ} \mathrm{C}$ and acid volatilization, respectively (Engleman et al., 1985), in USGS laboratories, Denver, CO. Weight percent TIC was converted to weight percent $\mathrm{CaCO}_{3}$ by dividing by 0.12 , the fraction of carbon in $\mathrm{CaCO}_{3}$. Total organic carbon (TOC) was determined as the difference 
between TC and TIC. The accuracy and precision for both TC and TIC usually are better than $0.10 \mathrm{wt} \%$.

Sediment for isotopic analysis was reacted with $2 \%$ sodium hypochlorite to remove organic matter and rinsed five times. The sediment was then sieved at $63 \mu \mathrm{m}$ to remove ostracodes, shell material, and charaphyte sheaths. The flow-through from the sieve was collected, freezedried, homogenized, and analyzed for carbon and oxygen isotopes on a Finnigan MAT 252 mass-spectrometer coupled to a Kiel II carbonate sampling device at the University of Minnesota. Results of analyses are reported in the usual per mil (\%) $\delta$-notation relative to the Vienna Pee Dee Belemnite carbonate standard (VPDB). The reproducibility on the Finnigan 252 is $0.06 \%$ for both oxygen and carbon.

\section{Chronology}

Six accelerator mass spectrometer radiocarbon dates $\left({ }^{14} \mathrm{C}\right.$ AMS $)$ were acquired on terrestrial macrofossils and calibrated with CALIB 5.0.2 (Stuiver and Reimer, 1993; Stuiver et al., 2005) (Table 1). Calibrated ages are the mean values of the $2 \sigma$ age range. All ages are reported as calibrated years before present (cal BP) where present $=$ AD 1950 .

An age-depth model was constructed using a combination of varve counts in the freeze core and radiocarbon dates (Fig. 2). Initially, it was anticipated that the varve counts would serve as the primary dating method, but difficulty counting the dark, extremely thin laminations $(\sim 0.3 \mathrm{~mm})$ resulted in significant offsets between the radiocarbon and varve chronologies. The resultant age model is based on (1) the assumption that the top of the freeze core is $\mathrm{AD} 2000$, (2) varve counts for the last century, and (3) five of the six AMS dates fit with a thirdorder polynomial to the age-depth data (Fig. 2). Varve counts from the freeze-core were tied stratigraphically to the long cores, providing ages for the last century (filled circles in Fig. 2). The date at $84.1 \mathrm{~cm}$ (italicized in Table 1) falls well off the general age-depth plot and was excluded in the age model. Inclusion of the date would suggest a very high sedimentation rate at 2500 cal BP, a result not supported by the uniformity and thinness of the laminations at this stratigraphic level.

\section{Results}

\subsection{Sediment description}

The sediment is calcareous/diatomaceous gyttja, consisting of fine light/dark couplets that range in thickness from 0.3 to $0.7 \mathrm{~mm}$. The sediment consists of four components: (1) detrital clastic material, (2) endogenic $\mathrm{CaCO}_{3}$ (as calcite), (3) terrestrial and lacustrine organic matter, and (4) biogenic silica (diatom frustules). The fraction of the detrital material was estimated based on aluminum and titanium contents and averages about 18\% (Whitlock et al., this volume). Percent $\mathrm{CaCO}_{3}$ content varies considerably but averages about $10 \%$ (Fig. 3c). Major decreases occur at ca. 2550, 1050, 900, 650-450 and $50 \mathrm{cal}$ BP. Sediments deposited between 1950 and 1350 cal BP have exceptionally low carbonate values, typically less than $5 \%$ but in many samples less than $2 \%$. Values of TOC average about $10 \%$ for the entire record (Fig. 3d). Sediments deposited prior to $2100 \mathrm{cal}$ BP have TOC values that are consistently lower than average. Percent organic matter, which is typically about twice TOC values (Dean, 1974 ), is about $20 \%$ on average. The sum of approximations for average detrital material, $\mathrm{CaCO}_{3}$, and organic

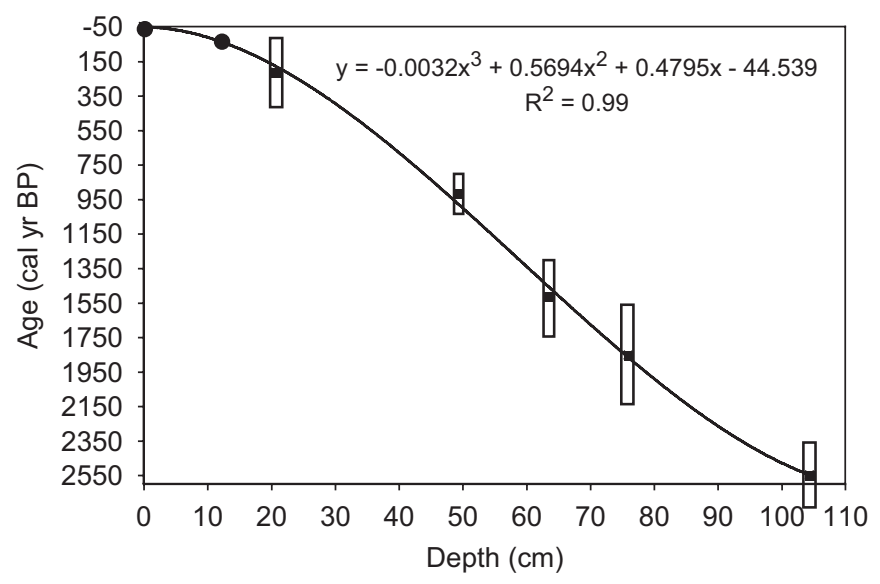

Fig. 2. Age-depth model for the upper $115 \mathrm{~cm}$ based on calibrated radiocarbon ages (squares, Table 1) and varve counts (circles). Unfilled rectangles around black squares indicate the $2 \sigma$ error bar for each calibrated age. Varve counts have no error estimates. Cal BP indicates age before AD 1950. Negative ages denote years after AD 1950.

Table 1

Radiocarbon ages and calibrated age equivalents used in constructing the Crevice Lake age model

\begin{tabular}{lllccc}
\hline Depth $(\mathrm{cm})$ & Material & Lab ID & Uncalibrated age & 2 $\sigma$ Calibrated range & Calibrated value (cal BP) \\
\hline 20.7 & Needle & WW-4618 & $210 \pm 55$ & $0-427$ & 210 \\
49.4 & Needle & WW-4619 & $1010 \pm 55$ & $791-1010$ & 900 \\
63.5 & Needle & WW-4625 & $1610 \pm 120$ & $1298-1741$ & 1520 \\
76 & Needle & WW-4626 & $1920 \pm 120$ & $1562-2149$ & 1855 \\
84.1 & Bark & WW-4620 & $2390 \pm 45$ & $2337-2698$ & $2520^{\mathrm{a}}$ \\
104.4 & Needle & WW-4621 & $2500 \pm 80$ & $2362-2742$ & 2550 \\
\hline
\end{tabular}

Calibrated value is the mean of the $2 \sigma$ age range rounded to the nearest half decade.

${ }^{\text {a }}$ Not used in age-depth model. 


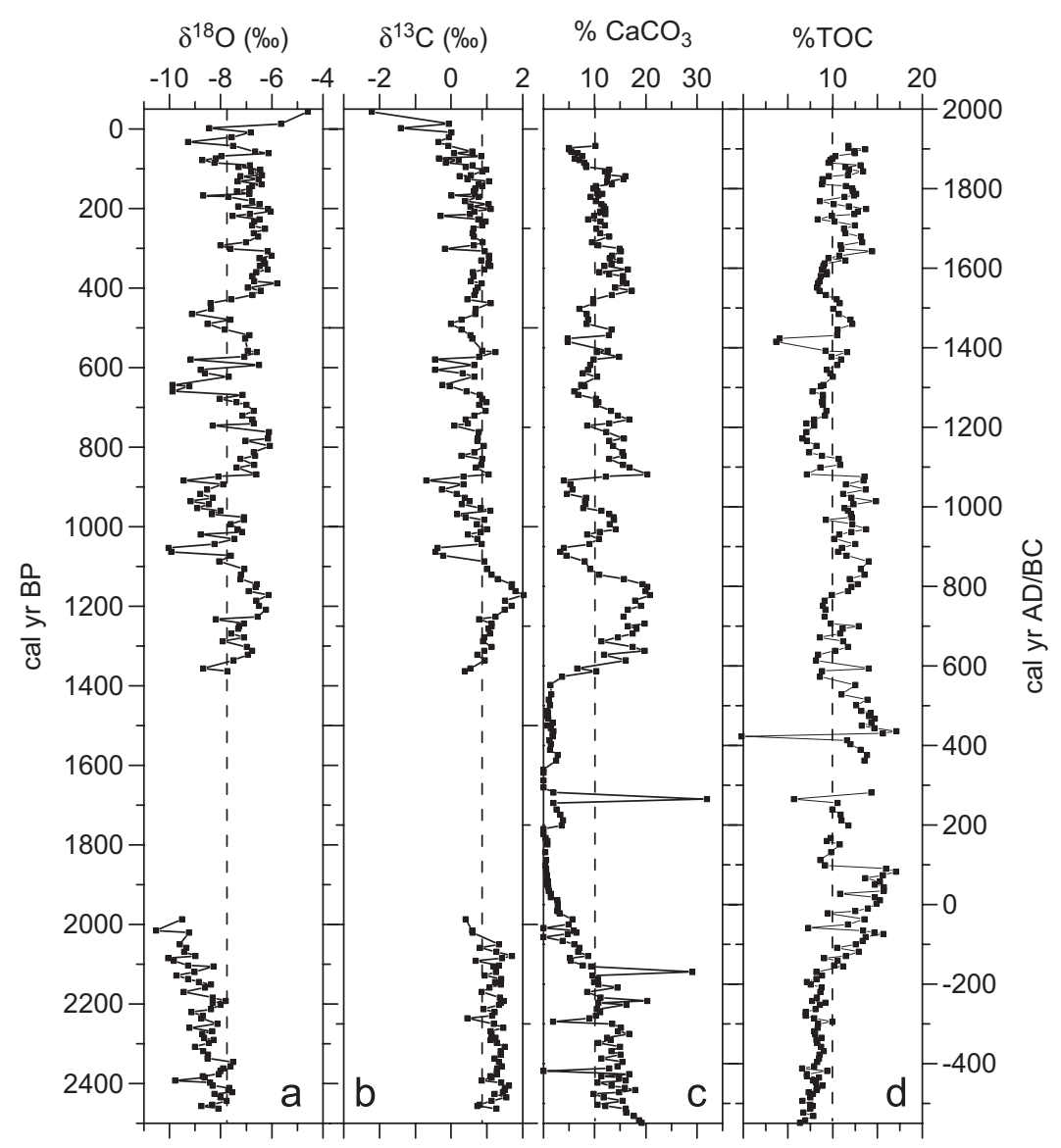

Fig. 3. Time-series for (a) $\delta^{18} \mathrm{O}$ values $(\% \mathrm{VPDB})$, (b) $\delta^{13} \mathrm{C}$ values (\% VPDB), (c) $\% \mathrm{CaCO}_{3}$, and (d) $\%$ TOC. Dashed lines indicate average values for reference.

matter is $48 \%$, which leaves over $50 \%$ for biogenic silica (Whitlock et al., this volume). Scattered throughout the core are orange-colored nodules and silt nodules that warp the laminations both up and down.

\subsection{Isotopic results}

The $\delta^{18} \mathrm{O}$ values of the $<63 \mu \mathrm{m}$ sediment fraction range from $-10.5 \%$ to $-4.5 \%$, with an average value of $-7.7 \%$ o (Fig. 3a). Between 2500 and 2000 cal BP, decadal variations in $\delta^{18} \mathrm{O}$ values are superimposed on a gradual decrease from ca. $-8 \%$ to $-10.5 \%$. A gap in the record between 2000 and 1350 cal BP is due to insufficient carbonate in the sediment for isotopic analysis. After 1350 cal BP, the record exhibits both centennial- and decadalscale variations. Several intervals have $\delta^{18} \mathrm{O}$ values that are significantly lower than average: 1090-1030, 970-870, 670-620, and 500-430 cal BP (Fig. 3a). A notable increase to the highest values of the record occurs in the latter half of the 20th century.

Values of $\delta^{13} \mathrm{C}$ range from $-0.3 \%$ to $+2.0 \%$, with an average value of $+0.8 \%$ (Fig. 3b). During the first 500 years, $\delta^{13} \mathrm{C}$ values are relatively uniform and above the long-term average. After $1350 \mathrm{cal} \mathrm{BP}, \delta^{13} \mathrm{C}$ variations increase in amplitude and at first approximation mirror those of the $\delta^{18} \mathrm{O}$ record (Fig. 3b). However, this apparent covariance does not hold true at short time-scales (i.e., decadal-scale). Similarly, both records correlate on longer time scales with changes in the $\% \mathrm{CaCO}_{3}$, but not at the decadal scale. Lack of correlation at decadal scales cannot be the result of sampling resolution as all proxy aliquots came from the same original sample.

\section{Discussion}

\section{1. $\delta^{18}$ O-inferred hydroclimate history}

Interpretation of the $\delta^{18} \mathrm{O}$ record from Crevice Lake must take into consideration the hydrologic framework of the basin. The lack of any surface inputs or outputs suggests that water level in the lake is maintained through overland run-off and ground water influx. Except during spring snowmelt, the former is likely a minor component, especially given the small size of the catchment (ca. $0.5 \mathrm{~km}^{2}$ ). Rather, it is likely that the lake is maintained by shallow aquifers and is also hydrologically connected to the Yellowstone River. Although no ground water flow data were collected, the fact that the lake is situated in reworked till, located at a bend in the river, and that the elevation of the lake surface is similar to the stream surface 
suggests that there could be a head gradient from upstream through the lake and back downstream (cf. Woessner, 2000). Further research will be necessary to document the relationship of the ground water flow path with the depositional structures, discharge rates and the hydraulic conductivity of the sediments surrounding the lake.

Comparison of the oxygen-isotopic record with independent measures of climate suggests that the annual moisture balance is the primary isotopic control, with the seasonal timing of precipitation providing a possible secondary influence. High $\delta^{18} \mathrm{O}$ values are associated with dry climate (e.g., evaporative enrichment of ${ }^{18} \mathrm{O}$ ) and/or wet summers relative to winters (higher $\delta^{18} \mathrm{O}$ values of atmospheric precipitation). Conversely, low $\delta^{18} \mathrm{O}$ values are interpreted as indicating a wetter climate and/or wet winters relative to summers. Three lines of evidence support the moisture balance model and link the $\delta^{18} \mathrm{O}$ values to synoptic climate features that control moisture in the region. First, relatively high $\delta^{18} \mathrm{O}$ values occurred during the AD 1930s drought, which is consistent with evaporative enrichment of lake water during drought. Furthermore, the general trend of the $\delta^{18} \mathrm{O}$ record over the last century matches both the Palmer Hydrologic Drought (PHDI) and Pacific Decadal Oscillation (PDO) (NCDC, 2006) indices, such that high $\delta^{18} \mathrm{O}$ values coincide with drought conditions and the warm phase of the PDO index (Fig. 4).

Second, a comparison of the $\delta^{18} \mathrm{O}$ record with tree-ring inferred annual discharge for the Yellowstone River (Graumlich et al., 2003) indicates that, within chronological errors, years of high stream-flow correspond in timing with low $\delta^{18} \mathrm{O}$ values (Fig. 5). There is also good correspondence between the inferred volume of flow and the relative shifts in the $\delta^{18} \mathrm{O}$ values, although the latter capture episodes of high flow better than low flow. Because high annual discharge for the Yellowstone River is linked to heavy snowmelt and wet winters (Graumlich et al., 2003), we infer that low $\delta^{18} \mathrm{O}$ values are related to wetter climate, in general, and wetter winters, in particular. The positive correlation between low $\delta^{18} \mathrm{O}$ values and high discharge could result from more than one mechanism. First, high discharge results from high volumes of snowmelt, which is typically depleted in ${ }^{18} \mathrm{O}$. Second, if ground water flux from the river to the lake increases with periods of high discharge, then lake water residence time would decrease, as would the evaporative enrichment of ${ }^{18} \mathrm{O}$.

Finally, increases in precipitation for the greater Yellowstone area inferred from tree rings (Gray et al., 2007) correspond with decreases in $\delta^{18} \mathrm{O}$ values at Crevice Lake for the periods of 700-550 cal BP and 250-0 cal BP (Fig. 6). It is notable that the two records are decoupled in the middle of the Little Ice Age (LIA) (550-250 cal BP) and in the latter part of the 20th century. The most obvious discrepancy between the two records is the pronounced wet period inferred from the isotopes between 520 and $440 \mathrm{cal}$ BP. This "wet" period corresponds to below average

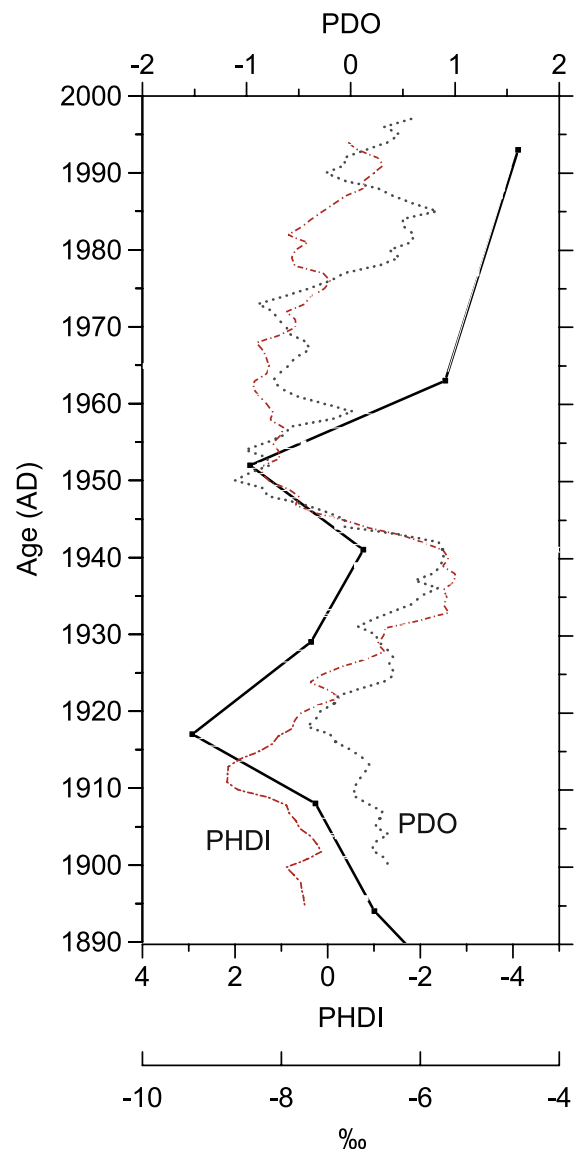

Fig. 4. $\delta^{18} \mathrm{O}$ record (solid line) versus Palmer Hydrologic Drought Index (PHDI, dashed line) and Pacific Decadal Oscillation index (PDO, dotted line) (http://www.ncdc.noaa.gov/oa/climateresearch.html). Large dashed line in the $\delta^{18} \mathrm{O}$ record indicates a gap in samples.

precipitation in the Yellowstone tree-ring record. Several possibilities could explain this decoupling. It could represent a warm interval in which little precipitation occurred but snow pack at high altitudes was steadily melted, providing discharge to the Yellowstone River. It is also possible that the period represents an unusually cold interval in which summer temperatures were depressed, evaporation of the lake water was minimal, and the little precipitation available was isotopically depleted snow. Depressed summer temperatures are consistent with those inferred from tree-rings in southern Canada (Luckman, 2000 ), and the lack of glacial advances supports dry conditions. Thus, the low $\delta^{18} \mathrm{O}$ values at Crevice Lake in the late 15th century, if indicative of high river discharge, are anomalous with some regional records. However, it should also be noted that this "wet" interval is contemporaneous with a short-lived wet event in northern Montana (Stevens et al., 2006) and a longer wet event at Walker Lake, Nevada (Yuan et al., 2004).

Although the seasonal timing of calcite precipitation may impact the $\delta^{18} \mathrm{O}$ value of the calcite, it does not appear to be a primary factor at Crevice Lake. The dominance of diatoms in the sediment suggests that calcite precipitation will be induced during the seasonal timing of the main 
diatom blooms. Between ca. 1400 and 400 cal BP, the $\delta^{18} \mathrm{O}$ record exhibits four large $(>2 \%$ ) oscillations. In the early part of the period (1400-800 cal BP), the diatom assemblage is dominated by Cyclotella bodanica, which

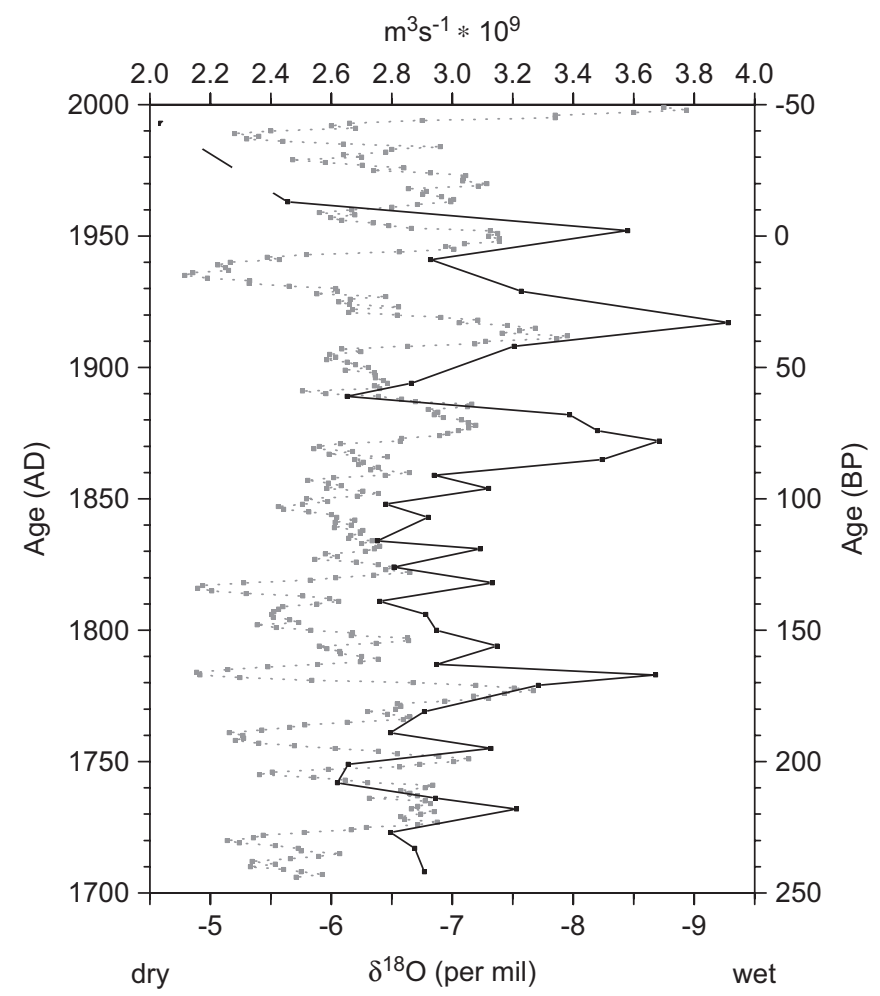

Fig. 5. $\delta^{18} \mathrm{O}$ profile (solid black) versus tree-ring inferred annual discharge for the Yellowstone River at Corwin Springs, Montana (dashed gray line, Graumlich et al., 2003) for the last 300 years. Annual discharge data are given as $\mathrm{m}^{3} \mathrm{~s}^{-1} \times 10^{9}$ and have been smoothed $(4 \%$ weighted least-squared error fit). Note the reversed scale for the $\delta^{18} \mathrm{O}$ values relative to Fig. 3c. blooms in the metalimnion during summer stratification. In the latter part (800-600 cal BP), the diatom assemblage is approximately $80 \%$ Stephanodiscus minutulus, which blooms during spring mixing (Bracht et al., this volume). The fact that these large $\delta^{18} \mathrm{O}$ fluctuations occur in both periods suggests that hydroclimate overrides any affects of the seasonal timing of calcite precipitation.

Overall, the $\delta^{18} \mathrm{O}$ record for Crevice Lake is atypical for most records derived from surficially-closed lakes in arid to semi-arid regions. Because these lakes often have longer residence times, evaporative concentration of ${ }^{18} \mathrm{O}$ (e.g., increases in $\delta^{18} \mathrm{O}$ ) are associated with droughts. These drought events (positive $\delta^{18} \mathrm{O}$ excursions) are often more pronounced than other hydrologic shifts. In Crevice Lake, negative deviations from the long-term average $\delta^{18} \mathrm{O}$ value are higher in magnitude than positive excursions, suggesting that the lake is more sensitive to wetter years than drier ones. Drought may be underrepresented in Crevice Lake relative to lakes in the adjacent northern Great Plains if flushing from the Yellowstone River dampens evaporative enrichment. Such isotopic dampening has been modeled for lakes in which high ground-water flow has reduced residence times (Shapley et al., in press).

Lower than average and generally decreasing $\delta^{18} \mathrm{O}$ values during the first 500 years of record suggest that the overall climate (or at least winters) became increasingly wetter from 2500 to $2000 \mathrm{cal}$ BP. Cool, wet winters would be consistent with prolonged periods of isothermal mixing in the water column suggested by the dominance of $S$. minutulus and Stephanodiscus medius in the diatom flora (Bracht et al., this volume).

The hydroclimatic history between 2000 and $1350 \mathrm{cal}$ BP cannot be determined from $\delta^{18} \mathrm{O}$ values due to the lack of calcite. Prior to this period, climate appeared to be getting

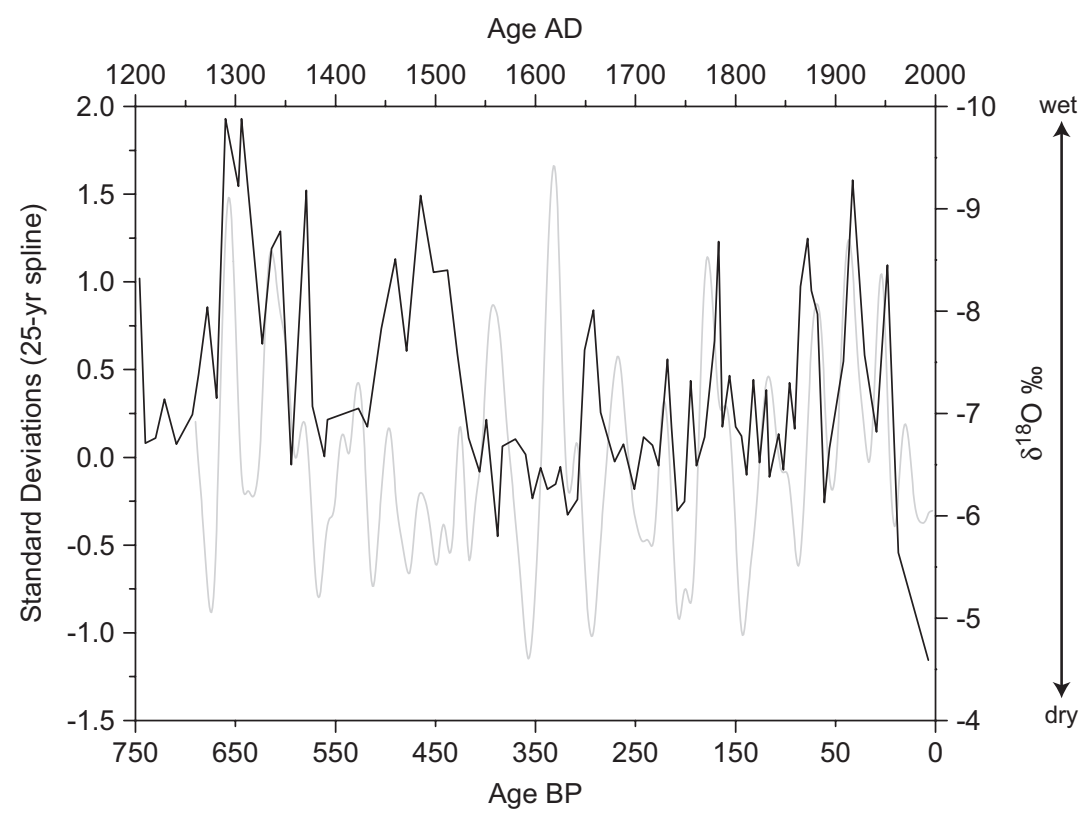

Fig. 6. Crevice Lake $\delta^{18} \mathrm{O}$ profile (black line) for the last 800 years compared to a 25 year spline (gray line) of tree-ring based precipitation estimates (as standard deviations) for the greater Yellowstone region (Gray et al., 2007). 
wetter. However, at $2100 \mathrm{cal} \mathrm{BP}$, when $\% \mathrm{CaCO}_{3}$ values begin to decrease, an abrupt shift in diatom species to C. bodanica and an increase in redox-sensitive metal concentrations indicate a change to protracted stratification of the water column. At the same time, pollen influx increases, suggesting warm and possibly long summers (Whitlock et al., this volume).

At ca. $1350 \mathrm{cal} \mathrm{BP}$, the isotopic record resumes. Over this interval, four periods had below average $\delta^{18} \mathrm{O}$ values, construed as unusually cool/wet climate with possibly deep snow pack: 1090-1030, 970-870, 670-620, and 500-430 cal BP. The wet intervals vary in duration from 60 to 100 years and intervening dry intervals range from 60 to 200 years. No definitive cyclicity is noted for the changes in hydroclimate.

During the latter part of the LIA (ca. 400-100 cal BP), $\delta^{18} \mathrm{O}$ values are uniform and mostly higher than the longterm average (Fig. 3a), suggesting a stable, dry climate with either low snow pack and/or limited spring melting of the snow pack because of colder summer temperatures. The latter scenario seems more likely given that colder summer temperatures would also help prolong spring mixing, as suggested by the dominance of the diatom $S$. minutulus (Bracht et al., this volume). Furthermore, tree-ring inferred estimates of precipitation in the greater Yellowstone area show no distinctive shift to generally drier conditions (Gray et al., 2007).

At the termination of the LIA (100 cal BP), the modern hydroclimate is established with large variations in $\delta^{18} \mathrm{O}$ values that coincide with changes in the PDO and PHDI (Fig. 4). This shift toward wetter climate is concomitant with a large decrease in $\delta^{13} \mathrm{C}$ values, although the latter likely reflects a decrease in atmospheric $\delta^{13} \mathrm{C}$ values associated with the combustion of fossil fuels during the last century. The wet intervals at AD 1875 and 1915 correspond in timing with flooding events upstream of Crevice Lake in the Lamar River basin (Meyer, 2001, Fig. 7). The marked shift at ca. AD 1960 to the highest $\delta^{18} \mathrm{O}$ values of the record is puzzling but may correspond with recent droughts, although high discharge in Yellowstone River would argue for low $\delta^{18} \mathrm{O}$ values (Fig. 5). The apparent de-coupling of the $\delta^{18} \mathrm{O}$ record from the discharge may simply be an artifact of sampling resolution (e.g., missing data might have low $\delta^{18} \mathrm{O}$ values that correspond with the peaks in discharge) rather than a true change in the hydrologic setting. However, it may also reflect an increase in the $\delta^{18} \mathrm{O}$ value of atmospheric precipitation in response to the increase in air temperatures at ca. AD 1960 identified in ice cores (Naftz et al., 2002).

\subsection{Relationship of $\delta^{18} \mathrm{O}, \delta^{13} \mathrm{C}$ values, and $\% \mathrm{CaCO}_{3}$}

$\delta^{18} \mathrm{O}$ and $\delta^{13} \mathrm{C}$ values show little correlation with other climatic proxies, except $\% \mathrm{CaCO}_{3}$. In general, when values of $\delta^{18} \mathrm{O}$ and $\delta^{13} \mathrm{C}$ are low, the carbonate content is low. (The relationship does not hold for high frequency fluctuations, and the correlation between $\delta^{18} \mathrm{O}$ and $\%$

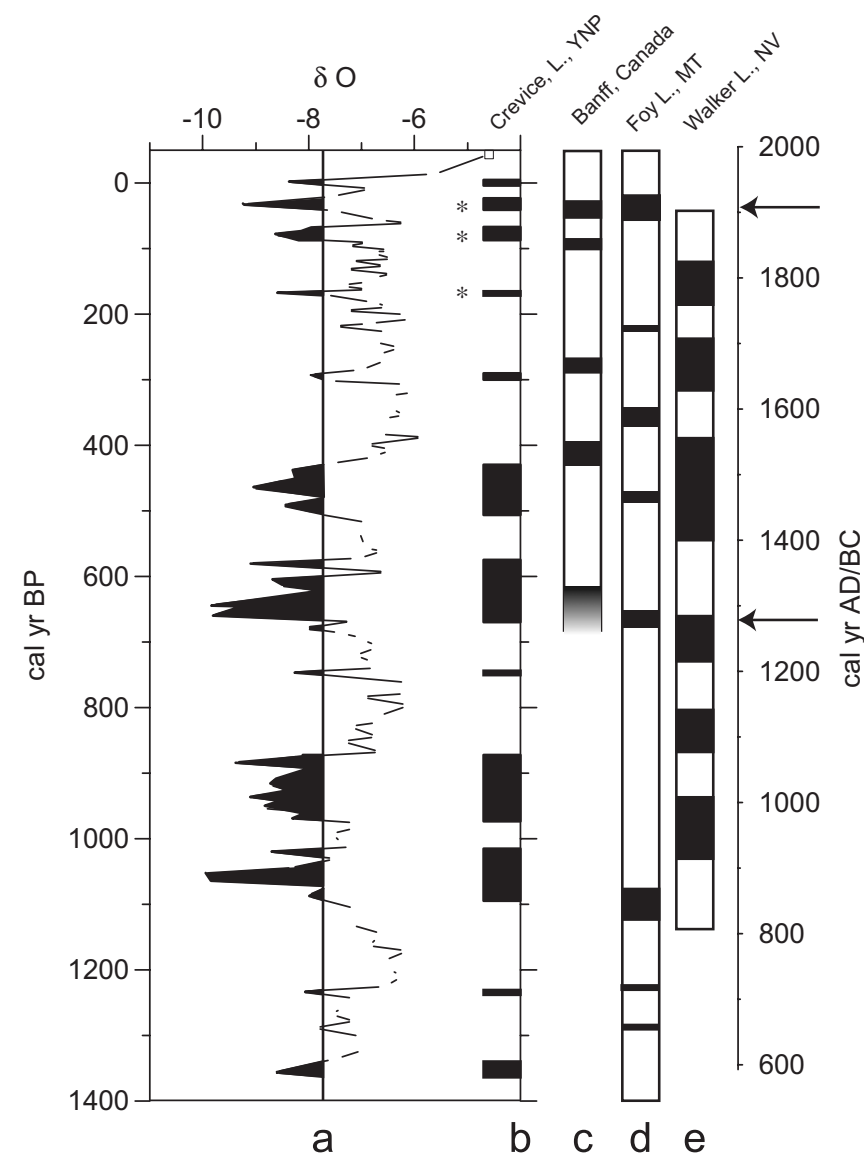

Fig. 7. Comparison of wet intervals identified in records from the western US. Wet intervals were defined as deviations from the long-term mean values in the original profiles and are denoted by black boxes. The raw Crevice Lake isotope record (a) is converted to a bar diagram (b) as an example. Stars in (b) represent tree-ring inferred flooding events in Yellowstone National Park (from Meyer, 2001). Other wet intervals are construed from (c) tree-ring estimates of precipitation at Banff, Canada (Watson and Luckman, 2004); (d) the $\delta^{18} \mathrm{O}$ record from Foy Lake, Montana (Stevens et al., 2006); (e) smoothed $\delta^{18} \mathrm{O}$ record from Walker Lake, Nevada (Yuan et al., 2004). Arrows on the right-hand axis indicate wet intervals common to all of these records.

$\mathrm{CaCO}_{3}$ has an $r^{2}$ of 0.22 .) The centennial-scale correlation between the isotopic values and $\% \mathrm{CaCO}_{3}$ suggests that there is either a mutual response to a common forcing mechanism or a causal relationship, where the amount of $\mathrm{CaCO}_{3}$ precipitated directly impacts the isotopic values.

The former situation (common forcing) requires an understanding of the controls on $\mathrm{CaCO}_{3}$ precipitation. The most notable feature of the $\mathrm{CaCO}_{3}$ record is the rapid decline to near $0 \%$ at about 1900 cal BP. The lack of carbonate could result from either low rates of production in the water column or high rates of dissolution in the water column and/or in the sediments. If climate of the region was becoming wetter, as suggested by the $2 \%$ decrease in $\delta^{18} \mathrm{O}$ values between 2400 and 2000 cal BP, then the lake water may have become dilute to the point where carbonate precipitation was much reduced or eliminated altogether. On the other hand, if productivity increased 
after $2100 \mathrm{BP}$, as suggested by the $\sim 6 \%$ increase in TOC, then photosynthetic removal of $\mathrm{CO}_{2}$ might have triggered more precipitation of $\mathrm{CaCO}_{3}$ in the epilimnion. However, respiration of organic matter in the hypolimnion would have increased the $\mathrm{CO}_{2}$ content and decreased the $\mathrm{pH}$ such that any $\mathrm{CaCO}_{3}$ produced at the surface would be dissolved in corrosive anoxic bottom waters (Dean and Schwalb, 2002). The levels of $\mathrm{CO}_{2}$ may have been exacerbated by protracted anoxia caused by marked summer stratification as suggested by the shift to $C$. bodanica (Bracht et al., this volume) and higher concentrations of redox-sensitive trace elements (e.g., molybdenum, uranium and sulfur) at 2100 cal BP (Whitlock et al., this volume). Thus, it is most likely that between 2100 and 1400 cal BP in Crevice Lake production of organic matter and carbonate dissolution won out over carbonate production.

After $1400 \mathrm{cal} \mathrm{BP}$, there are four intervals in which the amount of $\mathrm{CaCO}_{3}$ preserved in the sediments decreased, although it was not totally eliminated. According to the dissolution model above, these four periods likely represent episodes of prolonged stratification and oxygen-deficient bottom waters - a scenario supported by small increases in the concentrations of redox-sensitive trace elements (Whitlock et al., this volume). The fact that decreases in $\% \mathrm{CaCO}_{3}$, which are linked to stratification, are associated with decreases in $\delta^{18} \mathrm{O}$ values, which are linked to wet winters, adds a layer of complexity to the environmental reconstruction. It is possible, but unlikely, that preferential dissolution of calcite with high $\delta^{18} \mathrm{O}$ values occurs during periods of stratification. In other words, if dissolution is the cause of the decreases in $\% \mathrm{CaCO}_{3}$, there is little reason that the $\delta^{18} \mathrm{O}$ should decrease as well. A more likely possibility is that wet winters with high snow pack result in a spring influx of dilute water to the lake creating a pycnocline that suppresses thermal mixing. The dilute melt water would have low $\delta^{18} \mathrm{O}$ values, which would be transferred to the $\mathrm{CaCO}_{3}$, while the simultaneous onset of stratification would enhance build up of $\mathrm{CO}_{2}$ in the hypolimnion, causing dissolution of the $\mathrm{CaCO}_{3}$.

It is also possible that the correlation between $\delta^{18} \mathrm{O}$ and $\% \mathrm{CaCO}_{3}$ results from a causal relationship, whereby the amount of $\mathrm{CaCO}_{3}$ precipitation affects the isotopic composition through non-equilibrium fractionation. Depleted $\delta^{18} \mathrm{O}$ values have been described for large calcite grains from eutrophic systems (Teranes et al., 1999). However, there is no evidence for eutrophication at Crevice Lake during the last 2500 years and, in fact, the period from 2000 to $800 \mathrm{cal} \mathrm{BP}$ is dominated by C. bodanica, which can exist in low nutrient waters (Bracht et al., this volume). In addition, the lack of a correlation between the isotopes and the $\% \mathrm{CaCO}_{3}$ at decadal time scales argues against a causal relationship.

\subsection{Regional climate comparison}

A major question in paleoclimate research concerns the spatial extent of climate episodes. Given the climatic heterogeneity of mountain regions, this problem is acutely felt in western North America. Here we compare wet intervals in Crevice Lake with representative records from the northern Rocky Mountains and Great Basin/Sierra Nevada region (Fig. 7). In order to highlight the wet intervals only, each record was simplified to a bar graph by measuring the timing and duration of wet episodes. These are defined as deviations from the long-term mean values of each record. A bidecadal-smoothed record was used for Walker Lake, NV (Yuan et al., 2004). The simplification eliminates bias and confusion resulting from comparison among event magnitudes. Doing so is justified in that magnitudes of events can be, and often are, partly a function of an individual site's response to climatic forcing. However, this method also removes the climatic details of each event (rapidity of onset and cessation, ameliorations, etc.). We caution that this technique is meant only as a coarse measurement with which to look at the timing and duration of events.

Although the ultimate goal is to determine whether specific events are spatially coherent across great distances, rigorous comparisons among the sites is hampered by uncertainties in the chronologies. Small offsets in timing of events are likely the result of chronological discrepancies, but differences in duration may be dependent on the response time of individual proxies. The longer-duration events in the Walker Lake record are partly due to data smoothing.

Only two wet intervals, ca. 670 cal BP (AD 1280) and ca. 35 cal BP (AD 1915), are consistent among the four sites (arrows in Fig. 7). The younger event coincides with a weakly negative PDO index, but a strongly negative AMO (Atlantic Multidecadal Index) (McCabe et al., 2004). The older event is much more protracted at Crevice than at the other sites, which may be important to understanding regional climate coherency. Other wet events that show coherency among multiple sites occur at ca. 470 and $300 \mathrm{cal}$ BP. These events might result from a climatic configuration that includes both negative PDO and negative AMO regimes as outlined in McCabe et al. (2004).

Despite these similarities, most of the wet intervals identified in the four records are spatially asynchronous, confirming the climatic intricacies of mountainous regions. Even where records are in close geographic proximity (e.g., Banff, Foy, and Crevice), there is considerable offset in timing and duration of the identified wet intervals. For example, the wet interval at ca. $450 \mathrm{cal} \mathrm{BP}$ is one of the most severe and longest at both Banff and Crevice Lake, but is only minor in the western regional Drought Area Index (Cook et al., 2004) and is not evident at Foy Lake. Many of the differences occur during the latter part of the LIA (400-150 cal BP) and may result from heterogeneities of snow pack at each of the three sites. It should be noted that even glacial fluctuations can be locally complex (Luckman, 2000).

In contrast to the more northern sites, the number and timing of wet intervals at Crevice is most similar to those 
identified at Walker Lake, Nevada, although pronounced offsets exist during the Medieval Climate Anomaly (ca. $1100-800$ cal BP). Duration of the events is similar in some, but not all, instances. The similarity of these two records would suggest that during the latter part of the last 1000 years, the climate of the northern YNP was more in phase with the Great Basin region than with the Pacific Northwest. However, within the Medieval Climate Anomaly, there may be an anti-phase relationship between the hydroclimate of Crevice Lake and the Sierra Nevada and Great Basin regions. During the Medieval Climate Anomaly, two major droughts are recorded in the Sierra Nevada and western Great Basin by tree rings (Graumlich, 1993), tree stumps (Stine, 1994), and lake sediments (Benson et al., 2002) and the Southwestern US (see Benson et al., 2007, for a compilation). The first drought (ca. 1040-840 cal BP) overlaps in timing with a major wet interval at Crevice Lake that lasted from 970 to $870 \mathrm{cal}$ BP. The later drought (ca. 740-600 cal BP) encompasses the pronounced wet interval centered on $650 \mathrm{cal}$ BP. Dissimilar climates are not surprising given the observed responses to climatic phenomena, such as El Niño. Many more sites will be needed to produce a comprehensive spatial record of these wet events. However, because the climate of YNP exhibits commonalities to both the Pacific Northwest and the Great Basin regions, research in this area may help answer questions regarding the spatial distribution of synoptic climate patterns over long time scales across the greater western US.

\section{Conclusions}

The $\delta^{18} \mathrm{O}$ record from the varved sediment from Crevice Lake is a proxy for hydroclimate, particularly discharge of the Yellowstone River, in Yellowstone National Park. Low $\delta^{18} \mathrm{O}$ values are consistent with high flow of the Yellowstone River and, thus, wet winters with deep snow pack. They also correspond in general with tree-ring inferred estimates of increased precipitation in the YNP region. Prior to $2000 \mathrm{cal} \mathrm{BP}$, decreasing $\delta^{18} \mathrm{O}$ values suggest an increasingly wet climate or a gradual shift to winterdominated precipitation. A hiatus in the record from 2000 to 1350 cal BP results from dissolution of calcite in acidic bottom waters. Lack of an isotopic record for this period inhibits hydroclimatic interpretation. Other proxies suggest that this interval was drier, and the lake was likely stratified for long periods. During the last 1350 years, there have been several notable climatic events. Wet intervals are more pronounced than dry ones, probably because of the influence of the Yellowstone River on the hydrologic balance of the lake. Four distinct wet intervals occurred at 1090-1030, 970-870, 670-620, 500-430 cal BP. Shorter and less pronounced wet intervals occurred at 305-285, 87-65, and $35 \mathrm{cal} \mathrm{BP}$. All of these, with the exception of the oldest two, overlap with wet intervals in Banff, Canada and Walker Lake, Nevada, suggesting that they are broadly regional events. The marked aridity of the Medieval Period that is seen in the Sierra Nevada and western Great Basin is not evident at Yellowstone.

\section{Acknowledgments}

The authors gratefully acknowledge the assistance of K. Pierce, G. Skipp, J. Honke, L. Doner and J. Stone with coring. Logistical support was provided by the YNP Fire Cache staff. M. Solheid provided technical assistance with the isotope measurements. The manuscript was improved by the comments of L. Anderson, M. Shapley, S. Starratt, and two anonymous reviewers. The National Science Foundation (EAR-9905262), the Earth Surface Dynamics Program of the USGS, and the Canon Foundation provided funding for this project.

\section{References}

Almendinger, J.E., 1990. Groundwater control of closed-basin lake levels under steady-state conditions. Journal of Hydrology 112, 293-318.

Benson, L., Kashgarian, M., Rye, R., Lund, S., Paillet, F., Smoot, J., Kester, C., Mensing, S., Meko, D., Lindstrom, S., 2002. Holocene multidecadal and multicentennial droughts affecting Northern California and Nevada. Quaternary Science Reviews 21, 659-682.

Benson, L., Petersen, K., Stein, J., 2007. Anasazi (Pre-Columbian native American) migrations during the middle-12th and late-13th centuries - were they drought induced? Climatic Change 83, 187-213.

Bracht, B., Stone, J.R., Fritz, S.C., this volume. A diatom record of lateHolocene climate variation in the northern range of Yellowstone National Park, USA. Quaternary International, doi:10.1016/ j.quaint.2007.08.043.

Cayan, D.R., Kammerdiener, S.A., Dettinger, M.D., Caprio, J.M., Peterson, D.H., 2001. Changes in the onset of spring in the western United States. Bulletin of the American Meteorological Society 82, 399-415.

Cleaveland, M.K., Stahle, D.W., 1989. Tree ring analysis of surplus and deficit runoff in the White River, Arkansas. Water Resources Research 25, 1391-1401.

Cook, E.R., Woodhouse, C.A., Eakin, C.J., Meko, D.M., Stahle, D.W., 2004. Long-term aridity changes in the Western United States. Science 306, 1015-1018.

Dean, W.E., 1974. Determination of carbonate and organic matter in calcareous sediments and sedimentary rocks by loss on ignition: comparison with other methods. Journal of Sedimentary Petrology 44, 242-248.

Dean, W.E., Schwalb, A., 2002. The lacustrine carbon cycle as illuminated by the waters and sediments of two hydrologically distinct headwater lakes in North-central Minnesota, USA. Journal of Sedimentary Research 72, 416-431.

Engleman, E.E., Jackson, L.L., Norton, D.R., Fischer, A.G., 1985. Determination of carbonate carbon in geological materials by coulometric titration. Chemical Geology 53, 125-128.

Graumlich, L.J., 1993. A 1000-yr record of temperature and precipitation in the Sierra Nevada. Quaternary Research 39, 249-255.

Graumlich, L.J., Pisaric, M.F.J., Waggoner, L.A., Littell, J.S., King, J.C., 2003. Upper Yellowstone River flow and teleconnections with Pacific Basin climate variability during the past three centuries. Climatic Change 59, 245-262.

Gray, S.T., Graumlich, L.J., Betancourt, J.L., 2007. Annual precipitation in the Yellowstone National Park region since AD 1173. Quaternary Research 68, 18-27.

Luckman, B.H., 2000. The Little Ice Age in the Canadian Rockies. Geomorphology 32, 357-384. 
McCabe, G.J., Palecki, M.A., Betancourt, J.L., 2004. Pacific and Atlantic Ocean influences on multidecadal drought frequency in the United States. PNAS 101, 4136-4141.

Meyer, G.A., 2001. Recent large-magnitude floods and their impact on valley-floor environments of northeastern Yellowstone. Geomorphology 40, 271-290.

Mock, C.J., 1996. Climatic controls and spatial variations of precipitation in the Western United States. Journal of Climate 9, 1111-1125.

Mote, P.W., Hamlet, A.F., Clark, M.P., Lettenmaier, D.P., 2005. Declining mountain snowpack in western North America. Bulletin of the American Meteorological Society 86, 39-49.

Naftz, D.L., Susong, D.D., Schuster, P.F., Cecil, L.D., Dettinger, M.D., Michel, R.L., Kendall, C., 2002. Ice core evidence of rapid air temperature increases since 1960 in alpine areas of the Wind River Range, Wyoming, United States. Journal of Geophysical Research 107 (13), 1-16.

National Climate Data Center (NCDC), 2006. 〈http://www.ncdc.noaa.gov/oa/climate/research/teleconnect/teleconnect.html\#PDO $\rangle$.

Regonda, S.K., Rajagopalan, B., Clark, M., Pitlick, J., 2005. Seasonal cycle shifts in hydroclimatology over the Western United States. Journal of Climate 18, 372-384.

Shapley, M.D., Ito, E., Donovan, J.J., in press. Isotopic evolution and climate paleorecords in groundwater-dominated lakes. Journal of Paleolimnology.

Smith, L.P., Stockton, C.W., 1981. Reconstructed streamflow for the Salt and Verde Rivers from tree-ring data. Water Resources Bulletin 17, 939-947.

Stevens, L.R., Stone, J.R., Campbell, J., Fritz, S.C., 2006. A 2200-yr record of hydrologic variability from Foy Lake, Montana, USA, inferred from diatom and geochemical data. Quaternary Research 65, 264-274.

Stewart, I.T., Cayan, D.R., Dettinger, M.D., 2004. Changes in snowmelt runoff timing in Western North America under a 'Business as Usual' climate change scenario. Climatic Change 62, 217-232.
Stewart, I.T., Cayan, D.R., Dettinger, M.D., 2005. Changes toward earlier streamflow timing across western North America. Journal of Climate $18,1136-1155$.

Stine, S., 1994. Extreme and persistent drought in California and Patagonia during Mediaeval time. Nature 369, 549-564.

Stuiver, M., Reimer, P.J., 1993. Extended ${ }^{14} \mathrm{C}$ database and revised CALIB radiocarbon calibration program. Radiocarbon 35, 215-230.

Stuiver, M., Reimer, P.J., Reimer, R.W. 2005. CALIB 5.0 (WWW program and documentation).

Teranes, J.L., McKenzie, J.A., Lotter, A.F., Sturm, M., 1999. Stable isotope response to lake eutrophication: calibration of a highresolution lacustrine sequence from Baldeggersee, Switzerland. Limnology and Oceanography 44, 320-333.

USGS-National Water Information System, n.d. 〈http://waterdata.usgs. gov/usa/nwis $>$.

Watson, E., Luckman, B.H., 2004. Tree-ring based reconstructions of precipitation for the southern Canadian cordillera. Climatic Change 65, 209-241.

Whitlock, C., Dean, W.E., Rosenbaum, J., Stevens, L.R., Fritz, S.C., Bracht, B., Power, M., this volume. A 2650-year-long record of environmental change from northern Yellowstone Park based on a comparison of multiple proxy data. Quaternary International, doi:10.1016/j.quaint.2007.06.005.

Woessner, W.W., 2000. Stream and fluvial plain ground water interactions: rescaling hydrogeologic thought. Ground Water 38, 423-429.

Woodhouse, C.A., 2001. A tree-ring reconstruction of streamflow for the Colorado Front Range. Journal American Water Research Association 37, 561-569.

Yuan, F., Linsley, B.K., Lund, S.P., McGeehin, J.P., 2004. A 1200 year record of hydrologic variability in the Sierra Nevada from sediments in Walker Lake, Nevada. Geochemistry, Geophysics, Geosystems 5, $1-13$. 